\title{
Colombian Páramo Vegetation Database (CPVD) - the database on high Andean páramo vegetation in Colombia
}

\author{
Jesús Orlando Rangel-Churio \& Jairo Humberto Pinto-Zárate
}

\begin{abstract}
The Colombian Páramo Vegetation Database (CPVD; GIVD ID SA-CO-001) originates from the rush of phytosociological studies developed during the second half of the last century. The efforts of Spanish, Dutch and Colombian botanists have allowed almost the entire territory of the country where this natural region (páramo) is present to be covered. The database currently has records of approximately 1,000 plots representing at least 327 different physiognomic types such as shrubs, Espeletia stem rosettes and bunchgrasses established in localities of the three Andean Cordilleras and in the Caribbean massifs, Sierra Nevada de Santa Marta and Serranía de Perijá. The Eastern Cordillera, which is the most explored mountain range, contains the highest diversity and richness in vegetation types. The construction of the database has allowed us to start the delimitation and syntaxonomical classification of vegetation units, as can be seen in the most recent phytosociological treatments of the páramo vegetation of the Western Cordillera and the massifs of the Caribbean region. The database provides information for programs on conservation of associated flora and fauna species and restoration - recovery of vegetation types under imminent risk due to habitat loss. Also relevant are its applications in spatial delimitation of conservation reserves, development of thematic cartography, and precise definition of altitudinal limits of the páramo region for land use purposes.
\end{abstract}

Keywords: Andes; biodiversity; phytosociology.

Received: 04 November 2010 - Accepted: 3 October 2011 - Co-ordinating Editor: Gabriela Lopez-Gonzalez.

\section{Introduction}

The establishment of the vegetation characterization in Colombia, including the páramo region, has its historical origins in the contributions of Caldas and von Humboldt (van der Hammen \& Rangel-Churio 1997), actions extraordinarily boosted by Cuatrecasas-Arumí's contributions (Cuatrecasas-Arumí 1934), who described under geobotanical criteria several types of stem rosettes: Espeletietum hartwegianae-Calamagrostiosum, Hypericetosum and Sphagnosum (Central Cordillera), and Espeletietum argenteae-Calamagrostiosum (Eastern Cordillera), and also by the studies associated with 'The Quaternary of Colombia' program lead by Prof. Dr. Thomas van der Hammen (van der Hammen \& González 1960, van der Hammen 1973).

Among the most relevant contemporary contributions are those of LozanoContreras \& Schnetter (1976), Cleef (1981), Sturm \& Rangel-Churio (1985), Rangel-Churio \& Franco-Roselli (1985), Franco-Roselli et al. (1986), Duque-Nivia
\& Rangel-Churio (1989), SánchezMontaño \& Rangel-Churio (1990) and Salamanca-Villegas (1991). The 'Studies on Tropical Andean Ecosystems' program (ECOANDES) allowed the characterization of the páramo vegetation of Central (Salamanca-Villegas et al. 2003) and Western and Eastern Cordilleras (Cleef et al. 2005, Cleef et al. 2008). The evaluation of the isolated Caribbean massifs such as Sierra Nevada de Santa Marta and Serranía de Perijá was carried out by Cleef \& Rangel-Churio (1984) and Rangel-Churio \& Arellano-Peña (2007b). The abundant information from different sources has been gathered in the database, including precise physical and biotic aspects such as plot size, elevation and detailed inventory of plant species. Data related to geographical locations and the taxonomic identity of floristic elements are currently being updated (Pinto-Zárate \& Rangel-Churio 2010a), and the validation of the phytosociological nomenclature is being addressed. The first results based on this database for Western Cordillera and the Caribbean massifs were published by Pinto-Zárate \& RangelChurio (2010b, c).

\section{Characteristics of the Colom- bian páramo}

The páramo region in Colombia includes the extensive zones that crown the mountains, extended between the continuous upper limit of the middle mountain forest vegetation and the lower limit of the snow line. In most locations the soils have a thick layer of organic matter. The climate is very contrasting with cold humid nights and very sunny days, occasionally with intense radiation. According to annual rainfall, they can be classified as pluvial (above 4,000 mm), super-humid $(4,000$ 3,000 mm), humid (3,000-1,800 mm), semi-humid (1,800-1,200 mm) and dry (below 1,200 mm) (Rangel-Churio 2000c). Three life zones have been considered for the páramo region, showing physical and biotic characteristics clearly defined (Cuatrecasas-Arumí 1958, Cleef 1981, Rangel-Churio 1991, 2000b, Lut- 
eyn 1999, Salamanca-Villegas et al. 2003): subpáramo, grass páramo and superpáramo. The subpáramo ('lower páramo', 'shrub páramo'), from 3,200 $(3,100)$ to $3,500(3,600) \mathrm{m}$ a.s.l., has a predominance of shrubby vegetation types. The grass páramo ('middle páramo', 'páramo properly said', 'proper páramo'), from $3,500(3,600)$ to 4,100 m.a.s.l., is dominated by Espeletia stem rosettes and bunchgrasses. The superpáramo ('upper páramo'), from 4,100 m a.s.l. to the lower snow line, shows a very characteristic discontinuity of meadow vegetation and an elevated amount of bare soil.

\section{GIVD Database ID: SA-CO-001}

Last update: 2012-07-11

\section{Colombian Páramo Vegetation Database (CPVD)}

Scope: The Colombian Páramo Vegetation Database (CPVD) summarizes the main floristic and environmental information about relevés of zonal, azonal and extra-zonal vegetation from Colombian high mountain (from (2500) 3000 to 4500 m.a.s.l.). It includes plots done by several researchers during the last four decades along the most important mountain massifs of the country: Eastern, Central and Western cordilleras, and massifs from Caribbean region.

Status: emerging Period: 1973-2006

Database manager(s): Jesús Orlando Rangel-Churio (jorangelc@gmail.com); Jairo Humberto Pinto-Zárate (jhpintoz@unal.edu.co) Owner: Jesús Orlando Rangel-Churio

Web address: [NA]

Availability: not yet available

Database format(s): Excel

Online upload: no

Online search: no

Publication: [NA]

Plot type(s): normal plots

Non-overlapping plots: 800

Export format(s): Excel

Total plot observations: 800

Plot-size range: $1-100 \mathrm{~m}^{2}$

Countries: CO: $100.0 \%$

Estimate of existing plots: 1,500

Number of sources: 45
Completeness: $53 \%$

Valid taxa: 1,500

Forest: [NA] - Non-forest: [NA]

Guilds: all vascular plants: 100\%; bryophytes (terricolous or aquatic): $100 \%$; lichens (terricolous or aquatic): 100\%; non-terricolous taxa (epiphytic, saxicolous, lignicolous): $100 \%$

Environmental data: altitude: $95 \%$; slope aspect: $30 \%$; slope inclination: $90 \%$; soil depth: $5 \%$; surface cover other than plants (open soil, litter, bare rock etc.): $95 \%$; soil pH: $10 \%$; other soil attributes: $20 \%$; land use categories: $30 \%$

Performance measure(s): cover: $100 \%$; number of individuals: $40 \%$; measurements like diameter or height of trees: $15 \%$

Geographic localisation: GPS coordinates (precision $25 \mathrm{~m}$ or less): $10 \%$; point coordinates less precise than GPS, up to $1 \mathrm{~km}$ : $60 \%$; small grid (not coarser than $10 \mathrm{~km}$ ): $10 \%$; political units or only on a coarser scale $(>10 \mathrm{~km}): 20 \%$

Sampling periods: $1970-1979: 25.0 \% ; 1980-1989: 50.0 \% ; 1990-1999: 15.0 \% ; 2000-2009: 10.0 \%$

Information as of 2012-07-20; further details and future updates available from http://www.givd.info/ID/SA-CO-001

According to the physiognomy, the zonal vegetation types include dwarf forests with a tree stratum of 8 to $10 \mathrm{~m}$ high dominated by one or two species, such as the forests of Escallonia myrtilloides, Hesperomeles ferruginea, and those of Polylepis sericea and $P$. quadrijuga. Scrubs with woody elements below $5 \mathrm{~m}$ high are generally dominated by species of Asteraceae (Diplostephium, Baccharis, Ageratina, Gynoxys), Hypericum (Hypericaceae-Clusiaceae) and Arcytophyllum (Rubiaceae). Grasslands and bunchgrasses are dominated by species of Poaceae of genera like Calamagrostis, Agrostis and Festuca, and low bamboo communities (chuscales) by Chusquea tessellata. Stem rosettes (frailejonales) are dominated by species of Espeletiinae (Espeletia, Espeletiopsis), and the meadows with a ground stratum by species of genera like Lachemilla, Acaena (Rosaceae), Draba (Brassicaceae) and Azorella (Apiaceae). Azonal communities include vascular cushions with Distichia muscoides
(Juncacae), Plantago rigida (Plantaginaceae) and Werneria (Asteraceae), and reed swamps with species of Carex and Rhynchospora (Cyperaceae), as well as riparian and submerged or emergent vegetation types in lakes and ponds (Plate A, B, C). Rangel-Churio (2000b) recorded 327 plant communities for the entire Colombian páramo region, with predominance of scrubs. Most of them are concentrated in the grass páramo (146), followed by the subpáramo (112) and then the superpáramo (69).

\section{Geographical scope of the study and the database}

Rangel-Churio (2000b) mentioned almost 1252 páramo locations in Colombia, distributed from $3000 \mathrm{~m}$ a.s.l. up to 4600 $\mathrm{m}$ a.s.l. in the three Andean cordilleras (Eastern, Central and Western) and in locations such as the Macizo Colombiano, the Nudo de Los Pastos and the Caribbean massifs, Sierra Nevada de Santa Marta and Serranía de Perijá, between $1^{\circ}$ and $11^{\circ}$ North latitude and $72^{\circ}$ and $78^{\circ}$ West longitude. About the Eastern Cordillera, the database includes locations of the departments of Arauca, Boyacá, Cundinamarca, Meta, Norte de Santander and Santander, bounded by the Páramo de Romeral to the North, the Sierra Nevada del Cocuy to the East, and the Sumapaz Natural National Park (PNN) to the Southwest. This information was compiled and initially homogenized by Hernández-Roa (2002) and Pinto-Zárate (2005). About the Central Cordillera, the database includes localities of the departments of Caldas, Cauca, Huila, Risaralda, Quindío and Tolima, with reference to Los Nevados PNN and Nevado del Huila PNN. The information about Macizo Colombiano and Nudo de Los Pastos, particularly related to the volcanoes Azufral, Bordoncillo, Chiles, Cumbal, Galeras and Puracé in the departments of Cauca and Nariño, come from several local phytosociological treatments (Duque- 
Nivia \& Rangel-Churio 1989, RangelChurio \& Ariza-Niño 2000). The phytosociological synthesis of páramo vegetation of Western Cordillera and Caribbean massifs was recently presented by PintoZárate \& Rangel-Churio (2010b, 2010c). The final treatment for the other Cordilleras is in preparation. The distribution of the main páramo localities registered in the database is shown in Figure 1.

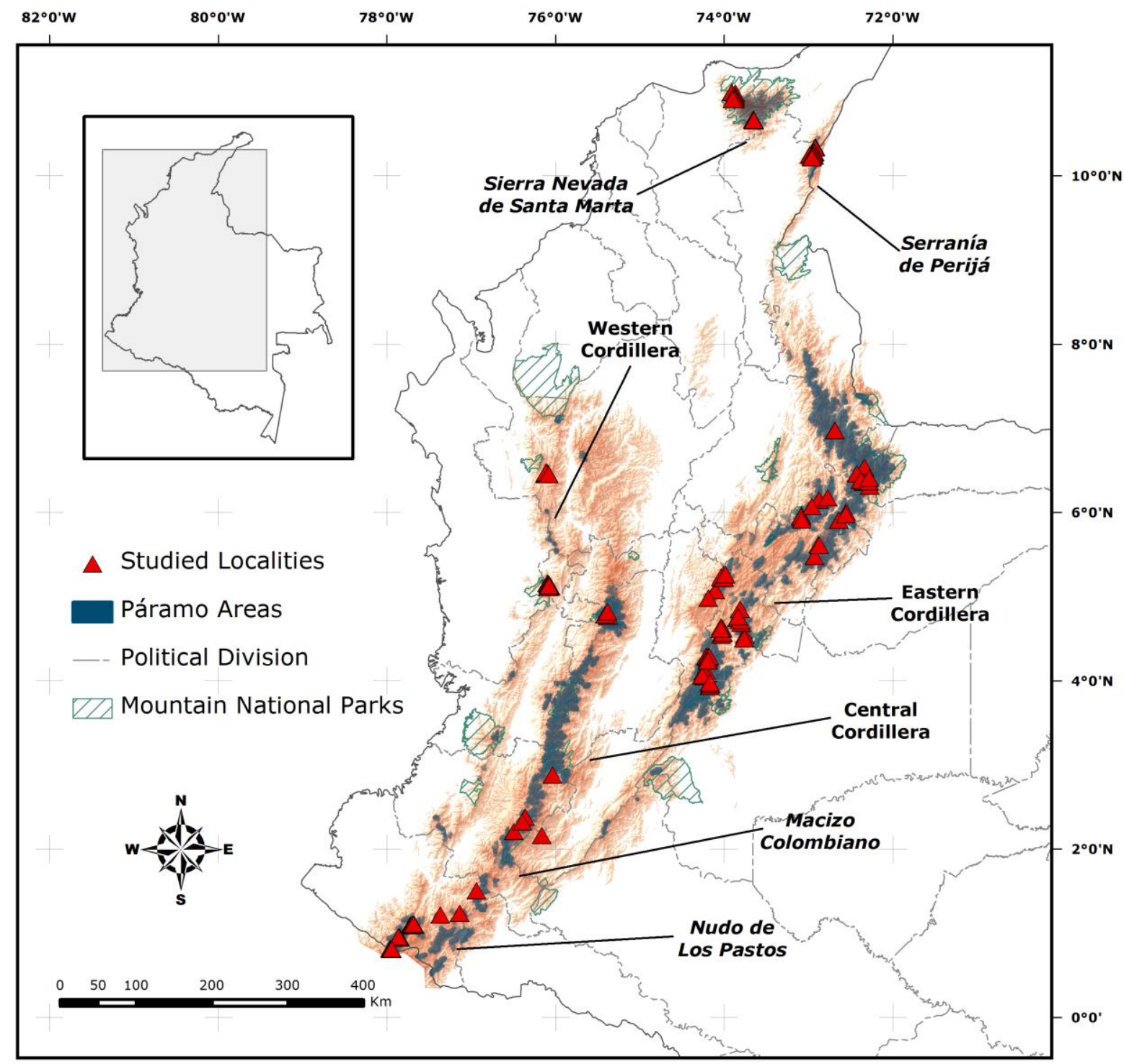

Fig. 1: Distribution of the high mountain localities included in the Colombian Páramo Vegetation Database (CPVD). Páramo areas: Rodríguez-Eraso et al. (2004), Morales-Rivas et al. (2007). Digital Elevation Model: NASA SRTM-90 m, $2000-02$ (>1,000 m.a.s.l.) (GLCF 2004). Geographic coordinates, datum Bogotá.

\section{Methodology}

Vegetation research in Colombia brings together the floristic approach of the classical Sigmatist school (BraunBlanquet 1979), followed by botanists and biologists who carried out exhaustive inventories of all species present in a given area, and the structural approach of forestry schools, which pays more attention to the inventory of arboreal and subarboreal species (Rangel-Churio \&
Velásquez 1997). The vegetation plots or relevés are sampled in bounded surfaces. In the case of the páramo vegetation, according to their appearance or physiognomic aspect they may vary between 1 and $50 \mathrm{~m}^{2}$ for shrubby and herbaceous communities (exceptionally large areas), and for dwarf forests between 100 and $250 \mathrm{~m}^{2}$. The formulation of RangelChurio \& Lozano-Contreras (1986) is followed to differentiate strata, taking into account the following height intervals of the individuals: $(\mathbf{r})$ : ground $(<0.3 \mathrm{~m})$; $(\mathbf{h})$ : herbaceous (0.3-1.49 m); (ar): shrubby (1.5-4.9 m); (A): sub-arboreal or of small trees $(5-11.9 \mathrm{~m})$. The plant cover or vertical projection of the aerial portion of individuals on the ground surface is estimated in square meters $\left(\mathrm{m}^{2}\right)$ and is subsequently converted to a percentage of the sampled area. The cover (\%) of each species in a stratum is the sum of the cover of its individuals. The number of individuals is an absolute number based 
on the field plots. In the case of relevés where there are measurements of diameter at breast height $(\mathrm{DBH})$, the basal area (BA) of each individual tree was calculated as follows: $\mathrm{BA}=(\pi / 4) \mathrm{DBH}^{2}$.

In the definition of the floristic composition patterns which characterize the different phytocoenoses, automated methods such as TWINSPAN (McCune \& Mefford 1999) were applied to identify the main separation trends among the sets of quadrats. The preliminary syntaxonomic units were differentiated, estimating the species fidelity according to the Szafer \& Pawlowsky scale (Braun-Blanquet 1979). Recently this procedure has been complemented with statistical fidelity measures (phi coefficient) according to the proposal of Chytrý et al. (2002). Such procedures were implemented using the JUICE software, version 7.0 (Tichý 2002). The final phytosociological scheme follows the recommendations of the International Code of Phytosociological Nomenclature (Weber et al. 2000, Izco \& del Arco 2003).

\section{Features of the database}

The Colombian Páramo Vegetation Database was developed with the purpose of gathering the main results of the last four decades of research on high Andean mountain vegetation in Colombia. This created for the first time an integrated information system covering diverse aspects relating to the phytosociological knowledge. Some of the most relevant issues are: geographical and altitudinal distribution of the relevés; taxonomic identity, relative cover and conservation status of each one of their floristic components (species); structural and environmental properties of the vegetation; literature sources; and hierarchical position in the syntaxonomical proposals developed by different authors (Box 1).

The information has been collected from different original sources, including field notes, internal reports, herbarium specimen labels, partial databases and published works, and integrated into a Microsoft Excel data matrix. The vegetation plots were sampled between 1970 and 2006 by several researchers along the main Colombian mountain ranges (Fig. 1). Most of the sampling was carried out during the 1980s (ca. 50\%). Approximately 800 relevés have been completely or almost completely computerized and georeferenced, representing $53 \%$ of the ca. 1500 quadrats estimated for the biome in the country. An exhaustive standardization procedure has been developed to ensure the quality of the data. A large number of floras and monographs have been consulted in order to confirm the botanical identity of the floristic elements and to update the taxonomic names. These focused on Colombia (Churchill \& Linares-Castillo 1995, Uribe-Meléndez \& Gradstein 1998, Aguirre-Ceballos 2008a, b), the local mountain massifs (RangelChurio \& Jaramillo-Mejía 1984, Sipman 1984, van Reenen et al. 1984, Carbonó \& Lozano-Contreras 1997, Parra et al. 2002, Rivera-Díaz \& Fernández-Alonso 2003, Calderón-Sáenz 2005, Rangel-Churio et al. 2005, Avendaño \& Aguirre-Ceballos 2007, Rivera-Díaz 2007), the páramo biome (Luteyn 1999, Linares-Castillo et al. 2000, Murillo 2000, Rangel-Churio et al. 2000, Sipman et al. 2000, UribeMeléndez \& Rangel-Churio 2000, Briceño \& Morillo 2002, 2006, RangelChurio \& Sánchez 2005, Sklenář et al. 2005, Vargas \& Gómez-Hoyos 2005), or specific taxonomic groups (Smith et al. 2006, Stančík \& Peterson 2007, APG 2009 , among others). Online plant checklists and databases were also helpful throughout this task (Hassler \& Swale 2001, USDA 2001, 2010, SI 2003, IPNI 2004, Luteyn \& Pedraza-Peñalosa 2007, BayScience Foundation 2010, CABI 2010, ICN 2010, MBG 2010a, b, NYBG 2010, RBG Kew \& MBG 2011).

We are currently working to develop an online relational database which will be made available to the public. We expect this tool will be useful for researchers, environmental authorities, decision makers and other people involved in the conservation and sustainable use of mountain natural resources in Colombia and Latin America.

\section{Box 1: Basic vegetation-plot information provided in the database SA-CO-001.}

Relevé information: Relevé ID / Author / Date / Area $\left(\mathrm{m}^{2}\right)$ / Number of species

Taxonomic information: Record ID / Cover: percentage - quantitative scale / Main taxonomic group: angiosperms - ferns and lycophytes - mosses - liverworts - lichens / Family / Genera / Specific epithet / Accepted species / Infraspecific ranks / Author citation / Original name recorded / Endemism / IUCN-CITES status / Collection number / Sources

Structural information: Physiognomy / Height / Strata cover (\%): ground - cushions - herbaceous - shrubby - arboreal - epiphytes / Components cover (\%): total - vascular - woody - grasses - bryophytes - lichens

Geographical information: Locality ID / Mountain range or massif: Eastern, Central or Western Cordilleras, Sierra Nevada de Santa Marta, Serranía de Perijá, Macizo Colombiano, Nudo de Los Pastos / Páramo name / Political division: department - municipality - district / Locality description / Elevation / Life zone / Geographic coordinates (Lat-Long): exact - approximate

Environmental information: Vegetation zonality / Disturbance / Slope / Exposition / Substrate attributes: classification - texture depth - acidity - soil bases - other elements (C, N, Al) - other properties / Water depth (aquatic and semi-aquatic environments)

Syntaxonomical information: Syntaxon ID / Correct name: principal ranks - supplementary ranks / Author citation / Synonyms Corresponding names / Previous classifications / Non-syntaxonomic proposals

Vegetation references: Source ID / Author / Year / Relevé table / Page / Complete reference

* Information recorded from primary and secondary sources (when available) 


\section{Application of the knowledge generated from the database}

\section{Case study: The páramo vegeta- tion of Colombian Western Cordil- lera and the Caribbean massifs}

The zonal páramo vegetation from Colombian Western Cordillera is represented in 28 syntaxonomic units (Box 2). These include fourteen associations, five subassociations, five alliances and three orders integrated in a single zonal and extrazonal vegetation class for the páramo region of Frontino and the Tatamá National Natural Park (Pentacalio vaccinioidis-Calamagrostietea effusae). Among the plant associations, there were consi-dered: two types of shrubs of Pentacalia vaccinioides with Diplostephium rosmarinifolium and Aragoa occidentalis; three types of bamboo-shrubs of Chusquea tessellata, Monnina salicifolia and species of Diplostephium; four types of stem rosettes-bunchgrasses and shrubsrosettes of Espeletia hartwegiana and $E$. frontinoensis; one type of dwarf shrubs of Loricaria complanata and Diplostephium rupestre; one of shrubby bunchgrasses of Calamagrostis effusa with Loricaria colombiana; two types of grasses-sedges of Rhynchospora aristata, Carex bonplandii and Calamagrostis effusa; and one of bunchgrasses of Calamagrostis effusa with Arcytophyllum muticum (PintoZárate \& Rangel-Churio 2010c).

In the case of the páramos from northern Colombia, Sierra Nevada de Santa Marta and Serranía de Perijá, the plant formations are summarized in 28 zonal units gathered in fifteen associations, six subassociations, five alliances, one order and one class (Stevio lucidaeCalamagrostietea effusae), complemented by five associations and one subassociation of azonal vegetation (Pinto-Zárate \& Rangel-Churio 2010b). Regarding dry communities from the southern slope of the Sierra Nevada de Santa Marta (Obtegomerio caerulescentisLachemillion polylepidis), two shrubby bunchgrasses of Calamagrostis effusa and Festuca cf. sanctae-martae were identified, and one association of arboreal stem rosettes of Libanothamnus occultus. Another seven associations with dominant matrices of Calamagrostis effusa and $C$. intermedia tussocks were described from dry southern areas of the Serranía de Perijá (Hyperico magdaleniciCalamagrostietalia effusae), including low scrubs and stem rosettes of Arcytophyllum nitidum, Espeletia perijaensis and species of Hypericum and Bejaria, herbaceous vegetation of Lourteigia stoechadifolia and Orthrosanthus chimboracensis, and bunchgrasses of Muhlenbergia angustata (Box 3) (Pinto-Zárate \& Rangel-Churio 2010b).

The wet environments of the northwestern slope of the Sierra Nevada de Santa Marta include two associations of open and dense bunchgrasses of Calamagrostis cf. effusa with low shrubs and herbaceous or creeping elements such as Ranunculus spaniophyllus, Perissocoeleum purdiei and rosettes of Draba cheiranthoides, plenty of bryophytes (Ranunculo spaniophylliCalamagrostion effusae). On the northern side of the Serranía de Perijá there were identified three associations of bamboo shrubs of Chusquea tessellata in combination with tussocks of Calamagrostis intermedia, stem rosettes of Espeletia perijaensis and low shrubs of Arcytophyllum nitidum, Hypericum strictum and Pernettya prostrata (Hyperico stricti-Chusqueion tessellatae) (Box 3) (Pinto-Zárate \& Rangel-Churio 2010b).

The azonal vegetation units (Box 4) include several types of dry arboreal stem rosettes of Libanothamnus divisoriensis, wet sparse shrubs of Lachemilla polylepis, shrubby meadows with cushions of Xyris columbiana and low bushes of Hypericum magdalenicum, ground rosettes and meadows of Werneria pygmaea and Acaena cylindristachya, and vascular cushions of Azorella crenata (PintoZárate \& Rangel-Churio 2010b).

\section{Other applications of the database}

In terms of plant species (alpha diversity) and communities (beta diversity), the high Andean mountain region of Colombia is recognized as the most diverse in the biogeographical area (Luteyn 1999, Rangel-Churio 2006). The information gathered in the database has been helpful to assess the conservation status and the main threats to species and vegetation types established in the páramos. RangelChurio (2000a) considered that at least 69 (21\%) of the 327 plant communities documented until 2000 in the páramo region are at imminent risk due to habitat degradation. The most affected vegetation types are shrubs (27 types) and stem rosettes (10 types), while the strongest disturbance effects are expressed particularly in the subpáramo. Orchidaceae, Asteraceae and Bromeliaceae are among the plant families with the highest number of endangered species. The differentiation of relevés and vegetation types according to their physiognomy is also useful to evaluate the conservation status of páramo areas by geographical locations; generally the dominance of shrubby communities in the best preserved areas of Colombian páramo is clear (RangelChurio 2006, Arellano-Peña \& RangelChurio 2008).

Based on the phytosociological treatment of the páramo vegetation of the Serranía de Perijá, Rangel-Churio \& Arellano-Peña (2007a) developed detailed distribution maps which constitute the basic input to characterize and spatialize the ecosystems. The database information has also been applied in wildlife conservation programs, such as the protection of birds associated with Polylepis sericea and $P$. quadrijuga forests (coloraditos), two arboreal species found up to 4100 m.a.s.l. Their relictual populations provide habitat for several species of birds which depend on them for refuge, breeding zone and food supply (Rangel-Churio \& Arellano-Peña 2010).

\section{Final considerations}

The consolidation of the database on páramo vegetation will make it easier to obtain a clear definition of the different vegetation types and their geographical distribution ranges across the national territory. The database is therefore an essential tool in the definition of the natural limit of the páramo region in Colombia. This procedure is necessary for all the ecological land use plans, the regulation of mining resources exploitation, and for conservation programs focused on the preservation of natural areas of this key region, critical to ensure water supply for the huge population of the country settled in middle and low mountain areas.

The detailed information of the relevés is fundamental for assessing the conservation status and the health of páramo wild populations and ecosystems. The vegetation database and its phytosociological characterization will allow us to elaborate an appropriate thematic cartography, facilitating the comparison of the spatial distribution of species, populations and communities at local and regional scales throughout the biogeographical páramo region, from the Central American mountains of Costa Rica to the foothills of the Bolivian Amazonian slopes. 
Box 2: Syntaxonomical scheme accepted for the páramo vegetation of the Colombian Western Cordillera, according to the proposal of Pinto-Zárate \& Rangel-Churio (2010c).

Pentacalio vaccinioidis-Calamagrostietea effusae Rangel \& J. Pinto in J. Pinto \& Rangel 2010

Cortaderio nitidae-Baccharitetalia macranthae Rangel \& J. Pinto in J. Pinto \& Rangel 2010

Calamagrostio effusae-Rhynchosporion aristatae Rangel \& J. Pinto in J. Pinto \& Rangel 2010

Geranio sibbaldioidis-Rhynchosporetum aristatae Rangel \& J. Pinto in J. Pinto \& Rangel 2010

Rhynchosporo aristatae-Caricetum bonplandii Rangel \& J. Pinto in J. Pinto \& Rangel 2010

Diplostephio schultzii-Chusqueion tessellatae Rangel \& J. Pinto in J. Pinto \& Rangel 2010

Rhynchosporo aristatae-Monninetum salicifoliae Rangel \& J. Pinto in J. Pinto \& Rangel 2010

Cortaderio nitidae-Chusqueetum tessellatae Rangel \& J. Pinto in J. Pinto \& Rangel 2010

Alliancia Incertae Sedis

Diplostephio rosmarinifolii-Gaiadendretum punctati Rangel, Cleef \& Salamanca in Cleef, Rangel, Salamanca, C. Ariza

\& van Reenen 2005 em. J. Pinto \& Rangel 2010

Loricario complanatae-Calamagrostietalia effusae Rangel \& J. Pinto in J. Pinto \& Rangel 2010

Diplostephio rupestris-Chusqueion tessellatae Rangel \& J. Pinto in J. Pinto \& Rangel 2010

Diplostephio rupestris-Loricarietum complanatae Rangel \& J. Pinto in J. Pinto \& Rangel 2010

Diplostephio-Loricarietum oreoboletosum cleefii Rangel \& J. Pinto in J. Pinto \& Rangel 2010

Diplostephio-Loricarietum sphagnetosum magellanici Rangel \& J. Pinto in J. Pinto \& Rangel 2010

Diplostephio cinerascentis-Chusqueetum tessellatae Cleef, Rangel \& Salamanca in Cleef, Rangel, Salamanca, C.

Ariza \& van Reenen 2005 em. J. Pinto \& Rangel 2010

Diplostephio-Chusqueetum gaultherietosum anastomosantis Rangel \& J. Pinto in J. Pinto \& Rangel 2010

Diplostephio-Chusqueetum diplostephietosum schultzii Rangel \& J. Pinto in J. Pinto \& Rangel 2010

Diplostephio-Chusqueetum calamagrostietosum effusae Rangel \& J. Pinto in J. Pinto \& Rangel 2010

Alliancia Incertae Sedis

Sphagno magellanici-Calamagrostietum effusae Cleef, Rangel \& Salamanca in Cleef, Rangel, Salamanca, C. Ariza \&

van Reenen 2005 em. J. Pinto \& Rangel 2010

Halenio foliosae-Baccharitetalia tricuneatae Rangel, D. Sánchez \& C. Ariza 1999 em. J. Pinto \& Rangel 2010

Aragoo occidentalis-Espeletion frontinoensis Rangel, D. Sánchez \& C. Ariza 1999 em. J. Pinto \& Rangel 2010

Hieracio adenocephali-Espeletietum frontinoensis Rangel \& J. Pinto in J. Pinto \& Rangel 2010

Blechno loxensis-Espeletietum frontinoensis Rangel, D. Sánchez \& C. Ariza 1999 em. J. Pinto \& Rangel 2010

Halenio foliosae-Calamagrostion effusae Rangel \& J. Pinto in J. Pinto \& Rangel 2010

Espeletio frontinoensis-Calamagrostietum effusae Rangel \& J. Pinto in J. Pinto \& Rangel 2010

Hyperico juniperini-Pentacalietum vaccinioidis Rangel \& J. Pinto in J. Pinto \& Rangel 2010

Arcytophyllo mutici-Calamagrostietum effusae Rangel \& J. Pinto in J. Pinto \& Rangel 2010

Alliancia Incertae Sedis

Oreobolo venezuelensis-Achyroclinetum alatae Rangel, D. Sánchez \& C. Ariza 1999 


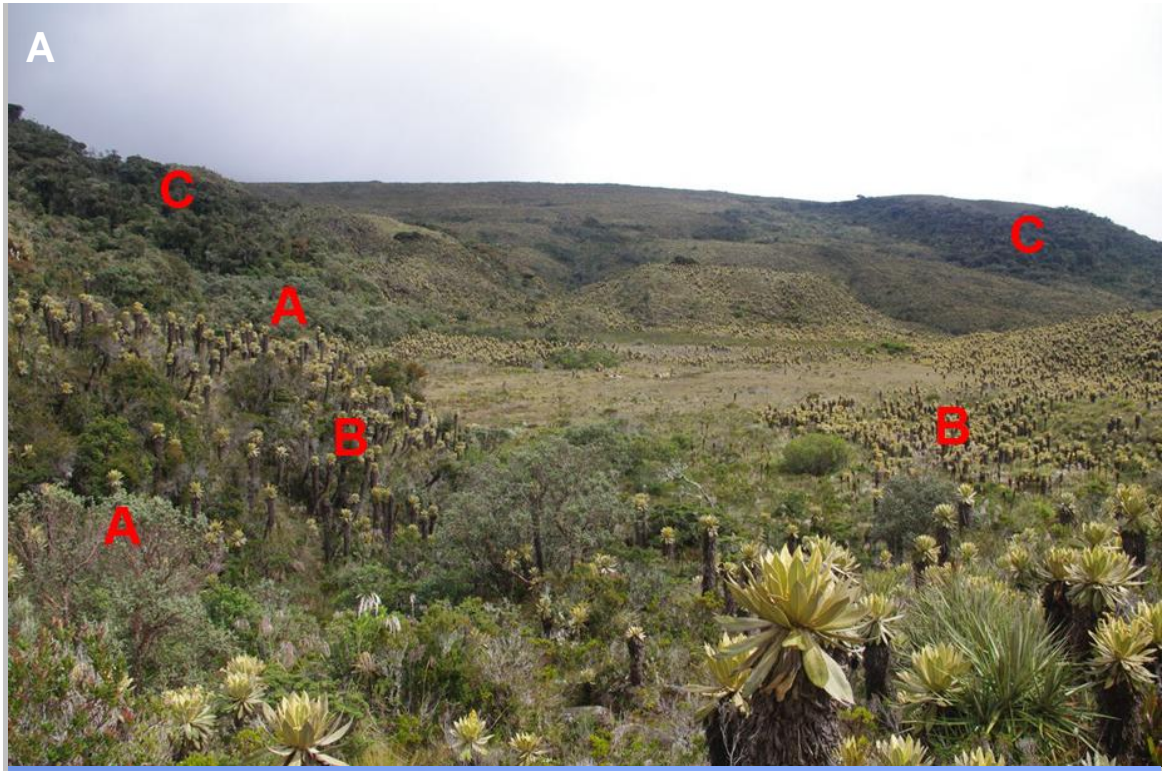

Plate: Vegetation types featured by the vegetation-plot database GIVD SA-CO-001.

A: Colombia: Antioquia, Páramo de Frontino, transition between high Andean forest and páramo, 3,600 m a.s.I. A: Elfin forest of Polylepis quadrijuga. B: Stem rosettes of Espeletia frontinoensis. C: High Andean forest of Miconia cf. jahnii and Myrsine parvifolia (Photo: L.N. Parra).

B: Colombia: Cesar, Serranía de Perijá, grass páramo, 3,600 m a.s.I. Dry arboreal stem rosettes of Libanothamnus divisoriensis (Holodisco argentei-

Libanothamnetum divisoriensis) (Photo: J.O. Rangel-Churio).

B

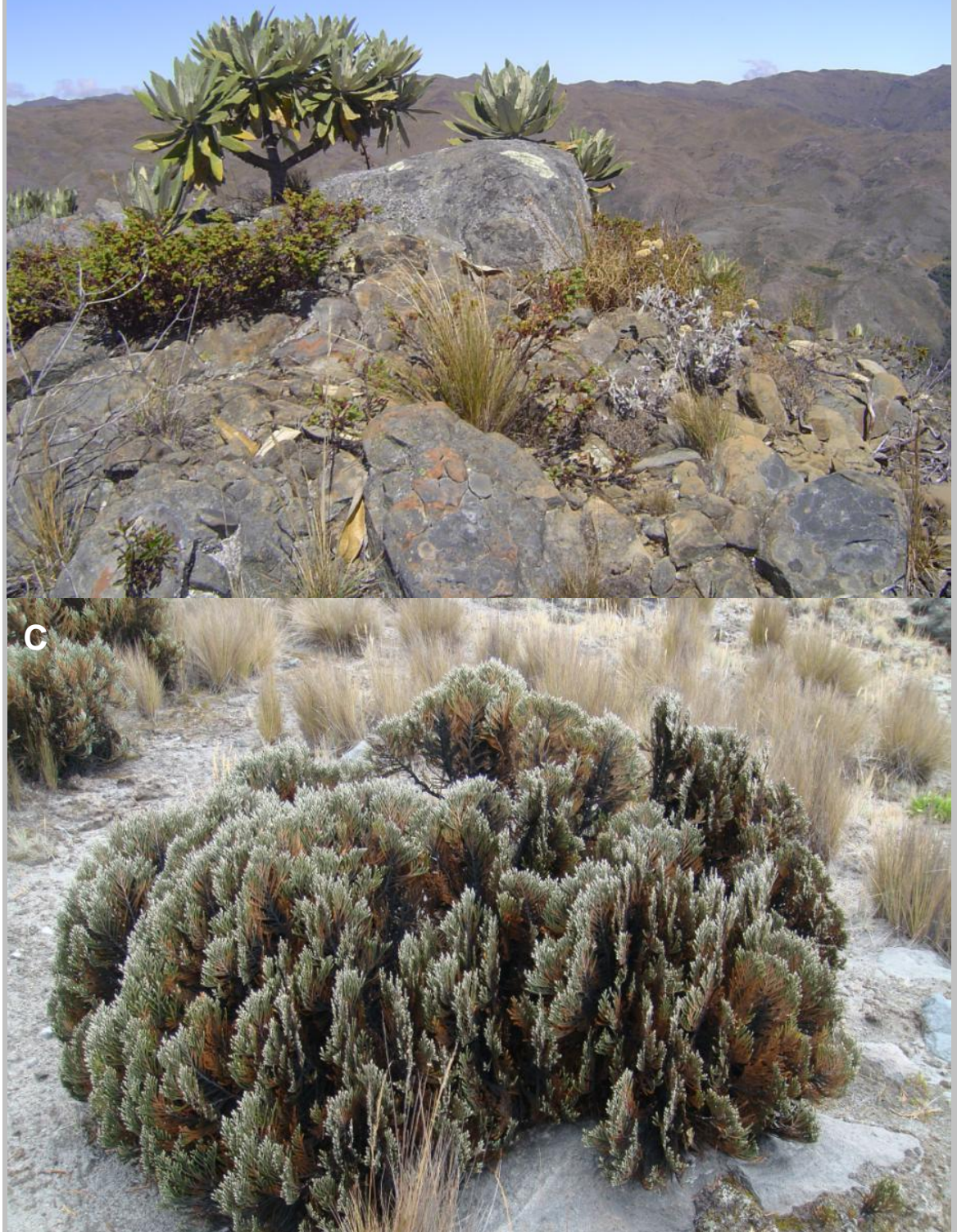

C: Colombia: Caldas-Tolima, Los Nevados PNN, low superpáramo, $4,290 \mathrm{~m}$ a.s.l. Dwarf scrubs of Loricaria colombiana (Photo: J.H. Pinto-Zárate). 
Box 3: Syntaxonomical scheme accepted for the zonal páramo vegetation of the massifs from Northern Colombia (Sierra Nevada de Santa Marta, Serranía de Perijá), according to the proposal of Pinto-Zárate \& Rangel-Churio (2010b).

\section{Dry formations}

Stevio lucidae-Calamagrostietea effusae Rangel \& Arellano ex J. Pinto \& Rangel 2010

Hyperico magdalenici-Calamagrostietalia effusae Rangel \& J. Pinto in J. Pinto \& Rangel 2010 Hyperico baccharoidis-Calamagrostion effusae Rangel \& Arellano ex J. Pinto \& Rangel 2010 Bejario resinosae-Hypericetum magdalenici Rangel \& J. Pinto in J. Pinto \& Rangel 2010 Bejario nanae-Calamagrostietum effusae Rangel \& J. Pinto in J. Pinto \& Rangel 2010

Bejario-Calamagrostietum gaiadendretosum punctati Rangel \& J. Pinto in J. Pinto \& Rangel 2010

Bejario-Calamagrostietum espeletietosum perijaensis Rangel \& J. Pinto in J. Pinto \& Rangel 2010 Gaylussacio buxifoliae-Arcytophylletum nitidi Rangel \& J. Pinto in J. Pinto \& Rangel 2010 Lourteigio stoechadifoliae-Calamagrostion effusae Rangel \& J. Pinto in J. Pinto \& Rangel 2010 Calamagrostio effusae-Espeletietum perijaensis Rangel \& J. Pinto in J. Pinto \& Rangel 2010 Calamagrostio intermediae-Lourteigietum stoechadifoliae Rangel \& J. Pinto in J. Pinto \& Rangel 2010 Calamagrostio effusae-Orthrosanthetum chimboracensis Rangel \& J. Pinto in J. Pinto \& Rangel 2010 Lourteigio stoechadifoliae-Muhlenbergietum angustatae Rangel \& J. Pinto in J. Pinto \& Rangel 2010 Ordo Incertae Sedis

Obtegomerio caerulescentis-Lachemillion polylepidis Rangel \& J. Pinto in J. Pinto \& Rangel 2010 Valeriano karstenii-Libanothamnetum occulti Rangel \& J. Pinto in J. Pinto \& Rangel 2010 Arcytophyllo nitidi-Festucetum sanctae-martae Rangel \& J. Pinto in J. Pinto \& Rangel 2010 Laennecio schiedeanae-Calamagrostietum effusae Rangel \& J. Pinto in J. Pinto \& Rangel 2010

\section{Wet formations}

Classis - Ordo Incertae Sedis

Ranunculo spaniophylli-Calamagrostion effusae Rangel \& J. Pinto in J. Pinto \& Rangel 2010

Drabo cheiranthoidis-Calamagrostietum effusae Cleef \& Rangel 1984

Drabo-Calamagrostietum erigerontetosum raphaelis Cleef \& Rangel 1984

Drabo-Calamagrostietum oligandretosum chrysocomatis Cleef \& Rangel 1984

Perissocoeleo purdiei-Calamagrostietum effusae Cleef \& Rangel 1984

\section{Classis - Ordo Incertae Sedis}

Hyperico stricti-Chusqueion tessellatae Rangel \& Arellano ex J. Pinto \& Rangel 2010

Espeletio perijaensis-Chusqueetum tessellatae Rangel \& Arellano ex J. Pinto \& Rangel 2010

Espeletio-Chusqueetum aetosum leucanthae Rangel \& J. Pinto in J. Pinto \& Rangel 2010

Espeletio-Chusqueetum perissocoeleetosum phylloidei Rangel \& J. Pinto in J. Pinto \& Rangel 2010 Arcytophyllo nitidi-Calamagrostietum intermediae Rangel \& Arellano ex J. Pinto \& Rangel 2010 Geranio holosericei-Chusqueetum tessellatae Rangel \& J. Pinto in J. Pinto \& Rangel 2010 
Box 4: Syntaxonomical scheme accepted for the azonal páramo vegetation of the massifs from Northern Colombia (Sierra Nevada de Santa Marta, Serranía de Perijá), according to the proposal of Pinto-Zárate \& Rangel-Churio (2010b).

Plantagini rigidae-Distichietea muscoidis Rivas-Martínez \& Tovar 1982

Oritrophio limnophili-Wernerietalia pygmaeae Cleef 1981

Wernerion crasso-pygmaeae Cleef 1981

Oritrophio limnophili-Wernerietum pygmaeae Cleef 1981 em. Cleef \& Rangel 1984

Oritrophio-Wernerietum typicum Cleef 1981 em. Cleef \& Rangel 1984

Classis - Ordo - Alliancia Incertae Sedis

Holodisco argentei-Libanothamnetum divisoriensis Rangel \& J. Pinto in J. Pinto \& Rangel 2010

Lachemilletum polylepidis Cleef \& Rangel ex J. Pinto \& Rangel 2010

Hyperico magdalenici-Xyridetum columbianae Rangel \& J. Pinto in J. Pinto \& Rangel 2010

Acaenetum cylindristachyae Cleef, Rangel \& van der Hammen in Cleef \& Rangel 1984

Azorelletum crenatae Cleef \& Rangel 1984

\section{Acknowledgements}

Special thanks to the tens of researchers and assistants who have collaborated over the years on the field data collection in the Colombian páramos. The present contribution was supported by the research project 'Valoración de la biodiversidad del Caribe colombiano: Síntesis del conocimiento y servicios ambientales' (Vicerrectoría de Investigación, Universidad Nacional de Colombia, Dirección de Investigación Sede Bogotá).

\section{References}

Aguirre-Ceballos, J. (2008a): Catálogo de los líquenes de Colombia. - In: RangelChurio, J.O. [Ed.]: Colombia Diversidad Biótica VI: Riqueza y diversidad de los musgos y líquenes de Colombia. 401547. Bogotá: Instituto de Ciencias Naturales, Universidad Nacional de Colombia.

Aguirre-Ceballos, J. (2008b): Catálogo de los musgos de Colombia. - In: RangelChurio, J.O. [Ed.]: Colombia Diversidad Biótica VI: Riqueza y diversidad de los musgos y líquenes de Colombia. 99319. Bogotá: Instituto de Ciencias Naturales, Universidad Nacional de Colombia.

APG - The Angiosperm Phylogeny Group. (2009): An update of the Angiosperm Phylogeny Group classification for the orders and families of flowering plants:
APG III. - Botanical Journal of the Linnean Society 161: 105-121.

Arellano-Peña, H., Rangel-Churio, J.O. (2008): Patrones en la distribución de la vegetación en áreas de páramo de Colombia: Heterogeneidad $y$ dependencia espacial. - Caldasia 30: 355-411.

Avendaño, K., Aguirre-Ceballos, J. (2007): La brioflora de la alta montaña de Perijá - In: Rangel-Churio, J.O. [Ed.]: Colombia diversidad biótica V: La alta montaña de la Serranía de Perijá. 133171. Bogotá: Instituto de Ciencias Naturales, CORPOCESAR.

Bayscience Foundation. (2010): ZipcodeZoo index to plant descriptions. - $\quad$ URL: http://zipcodezoo.com/Plants/Plantae. asp [accessed on 2008-2010].

Braun-Blanquet, J. (1979): Fitosociología: Bases para el estudio de las comunidades vegetales. 3rd ed. Madrid: H. Blume.

Briceño, B., Morillo, G. (2002): Catálogo abreviado de las plantas con flores de los páramos de Venezuela. Parte I. Dicotiledóneas (Magnoliopsida). - Acta Botanica Venezuelica 25: 1-46.

Briceño, B., Morillo, G. (2006): Catálogo de las plantas con flores de los páramos de Venezuela. Parte II. Monocotiledóneas (Liliopsida). - Acta Botanica Venezuelica 29: 89-134.

$\mathrm{CABI}$ - Centre for Agriculture and Biosciences International. (2010): Index Fungorum. - URL: http://www.index fungorum.org/Names/Names.asp [accessed on 2008-2010].

Calderón-Sáenz, Consideraciones geológicas (2005): ficas y florísticas sobre los Farallones de Cali. - In: van der Hammen, T., RangelChurio, J.O., Cleef, A.M. [Eds.]: La cordillera Occidental colombiana, transecto Tatamá. - Studies on Tropical Andean Ecosystems 6: 859-882. Berlin: J. Cramer.

Carbonó, E., Lozano-Contreras, G. (1997): Endemismos y otras singularidades de la Sierra Nevada de Santa Marta, Colombia. Posibles causas de origen y necesidad de conservarlos. - Revista de la Academia Colombiana de Ciencias Exactas, Físicas y Naturales 21(81): 409-419.

Churchill, S.P., Linares-Castillo, E.L. (1995): Prodromus Bryologiae NovoGranatensis: Introducción a la flora de musgos de Colombia. - Biblioteca José Jerónimo Triana 12. Volumes I - II. Bogotá: Instituto de Ciencias Naturales, Universidad Nacional de Colombia.

Chytrý, M., Tichý, L., Holt, J., Botta-Dukát, Z. (2002): Determination of diagnostic species with statistical fidelity measures. - Journal of Vegetation Science 13: 79_ 90.

Cleef, A.M. (1981): The vegetation of the páramos of the Colombian cordillera Oriental. - Dissertationes Botanicae 61. Vaduz: J. Cramer.

Cleef, A.M., Rangel-Churio, J.O. (1984): La vegetación del páramo del noroeste de la Sierra Nevada de Santa Marta. In: van der Hammen, T., Ruiz-Carranza, P.M. [Eds.]: La Sierra Nevada de Santa Marta (Colombia), transecto Buritaca-La Cumbre. - Studies on Tropical Andean Ecosystems 2: 203-266. Berlin: J. Cramer. 
Cleef, A.M., Rangel-Churio, J.O Salamanca-Villegas, S., Ariza-Niño, C.L., van Reenen, G.B.A. (2005): La vegetación del páramo del Macizo de Tatamá, cordillera Occidental, Colombia. - In: van der Hammen, T., RangelChurio, J.O., Cleef, A.M. [Eds.]: La cordillera Occidental colombiana, transecto Tatamá. - Studies on Tropical Andean Ecosystems 6: 377-468. Berlin: J. Cramer.

Cleef, A.M., Rangel-Churio, J.O., ArellanoPeña, H. (2008): The páramo vegetation of the Sumapaz massif (Eastern Cordillera, Colombia). - In: van der Hammen, T. [Ed.]: La cordillera Oriental colombiana, transecto Sumapaz. Studies on Tropical Andean Ecosystems 7: 799-913. Berlin: J. Cramer.

Cuatrecasas-Arumí, J. (1934): Observaciones geobotánicas en Colombia. - Trabajos del Museo Nacional de Ciencias Naturales Serie Botánica 27. Madrid: Museo Nacional de Ciencias Naturales.

Cuatrecasas-Arumí, J. (1958): Aspectos de la vegetación natural de Colombia. Revista de la Academia Colombiana de Ciencias Exactas, Físicas y Naturales 10(40): 221-268.

Duque-Nivia, A.A., Rangel-Churio, J.O (1989). Phytosociological analysis of the páramo vegetation of Puracé Natural Park. - In: Herrera, L.F., Drennan, R.D. Uribe, C.A. [Eds.]: Prehispanic chiefdoms in the Valle de La Plata, Volume 1. The environmental context of human habitation. - University of Pittsburgh Memoirs in Latin American Archaeology 2: 69-93. Pittsburgh: University of Pittsburgh.

Franco-Roselli, M.P., Rangel-Churio, J.O., Lozano-Contreras, G. (1986): Estudios ecológicos en la cordillera Oriental II: Las comunidades vegetales de los alrededores de la laguna de Chingaza. Caldasia 15(71-75): 219-248.

GLCF [Global Land Cover Facility] (2004): Earth Science Data Interface - ESDI. Version 2.1.17. - URL: http://glcfapp.glcf.umd.edu:8080/esdi/ind ex.jsp [accessed on 2009-06].

Hassler, M., Swale, B. (2001): Checklist of ferns and fern allies. - URL: http://homepages.caverock.net.nz/ bj/fe $\mathrm{rn} /$ list.htm [accessed on 2008-2010].

Hernández-Roa, J. (2002): La vegetación zonal de los páramos de la cordillera Oriental colombiana: Síntesis fitosociológica preliminar. Undergraduate thesis in Biology, Departamento de Biología, Universidad Nacional de Colombia [deposited at the library of the Universidad Nacional de Colombia - Sede Bogotá].

ICN [Instituto de Ciencias Naturales] (2010): Colecciones en línea. - URL http://www.biovirtual.unal.edu.co/ICN/ [accessed 2008-2010].
IPNI [International Plant Names Index] (2004): International Plant Names Index. - URL: http://www.ipni.org/index.html [accessed 2008-2010].

Izco, J., del Arco, M. (2003): Código Internacional de Nomenclatura Fitosociológica. Traducción de la 3a edición oficial. - Colección Materiales Didácticos Universitarios Serie Botánica 2. Santa Cruz de Tenerife: Universidad de La Laguna and Universidad de Santiago de Compostela.

Linares-Castillo, E.L., Aguirre-Ceballos, J., Rangel-Churio, J.O. (2000): Flora: Musgos. - In: Rangel-Churio, J.O. [Ed.]: Colombia diversidad biótica III: La región de vida paramuna. 473-527. Bogotá: Instituto de Ciencias Naturales, Instituto Alexander von Humboldt.

Lozano-Contreras, G., Schnetter, R. (1976): Estudios ecológicos en el páramo de Cruz Verde, Colombia II: Las comunidades vegetales. - Caldasia 11(54): 53-68.

Luteyn, J.L. (1999): Páramos. A checklist of plant diversity, geographical distribution, and botanical literature. - Memoirs of The New York Botanical Garden 84. Bronx: The New York Botanical Garden Press.

Luteyn, J.L., Pedraza-Peñalosa, P. (2007): Neotropical blueberries: The plant family Ericaceae. - URL: http://nybg.org/bsci/ res/lut2/main.html [accessed on 20082010].

MBG [Missouri Botanical Garden] (2010a): TROPICOS Andes Moss Project. 3rd version with Spanish translation. - URL: http://mobot.mobot.org/W3T/Search/and es/projsandes.html [accessed 20082010].

MBG [Missouri Botanical Garden] (2010b): TROPICOS nomenclatural database and associated authority files. - URL: http://www.tropicos.org/ [accessed 2008-2010]

McCune, B., Mefford, M.J. (1999): PCORD. Multivariate analysis of ecological data. Version 4.41. - Gleneden Beach: MjM Software.

Morales-Rivas, M., Otero-García, J., van der Hammen, T., Torres-Perdigón, A., Cadena-Vargas, C.E., PedrazaPeñaloza, C.A., Rodríguez-Eraso, N., Franco-Aguilera, C.A., BetancourthSuárez, J.C., Olaya-Ospina, E., PosadaGilede, E., Cárdenas-Valencia, L. (2007): Atlas de páramos de Colombia. - Bogotá: Instituto de Investigación de Recursos Biológicos Alexander von Humboldt.

Murillo, M.T. (2000): Flora: Helechos. - In: Rangel-Churio, J.O. [Ed.]: Colombia diversidad biótica III: La región de vida paramuna. 528-562. Bogotá: Instituto de Ciencias Naturales, Instituto Alexander von Humboldt.

NYBG [New York Botanical Garden] (2010): The C.V. Starr Virtual Herbarium. - URL: http://sciweb.nybg.
org/Science2/vii2.asp [accessed 20082010].

Parra, J.D., Callejas-Posada, R., Churchill, S.P. (2002): Los musci (musgos) del departamento de Antioquia. - Biota Colombiana 3: 163-192.

Pinto-Zárate, J.H. (2005): La vegetación azonal paramuna de la cordillera Oriental colombiana: Síntesis fitosociológica preliminar. Undergraduate thesis in Biology, Departamento de Biología, Universidad Nacional de Colombia [deposited at the library of the Universidad Nacional de Colombia - Sede Bogotá].

Pinto-Zárate, J.H., Rangel-Churio, J.O. (2010a): Flora asociada a las formaciones paramunas de la cordillera Occidental y el norte de Colombia (Sierra Nevada de Santa Marta, Serranía de Perijá), con base en parcelas de campo. - In: Rangel-Churio, J.O. [Ed.]: Colombia diversidad biótica $\mathbf{X}$ : Cambio global (natural) y climático (antrópico) en el páramo colombiano. 411-442. Bogotá: Instituto de Ciencias Naturales, Universidad Nacional de Colombia.

Pinto-Zárate, J.H., Rangel-Churio, J.O. (2010b): La vegetación de los páramos del norte de Colombia (Sierra Nevada de Santa Marta, Serranía de Perijá). In: Rangel-Churio, J.O. [Ed.]: Colombia diversidad biótica $\mathbf{X}$ : Cambio global (natural) y climático (antrópico) en el páramo colombiano. 289-410. Bogotá: Instituto de Ciencias Naturales, Universidad Nacional de Colombia.

Pinto-Zárate, J.H., Rangel-Churio, J.O. (2010c): La vegetación paramuna de la cordillera Occidental colombiana I: Las formaciones zonales. - In: RangelChurio, J.O. [Ed.]: Colombia diversidad biótica $\mathbf{X}$ : Cambio global (natural) y climático (antrópico) en el páramo colombiano. 181-287. Bogotá: Instituto de Ciencias Naturales, Universidad Nacional de Colombia.

Rangel-Churio, J.O. (1991): Vegetación y ambiente en tres gradientes montañosos de Colombia. - PhD thesis in Biology, University of Amsterdam [deposited at the library of the University of Amsterdam].

Rangel-Churio, J.O. (2000a): Flora y vegetación amenazada. - In: RangelChurio, J.O. [Ed.]: Colombia diversidad biótica III: La región de vida paramuna. 785-813. Bogotá: Instituto de Ciencias Naturales, Instituto Alexander von Humboldt.

Rangel-Churio, J.O. (2000b): La diversidad beta: Tipos de vegetación. - In: RangelChurio, J.O. [Ed.]: Colombia diversidad biótica III: La región de vida paramuna. 658-719. Bogotá: Instituto de Ciencias Naturales, Instituto Alexander von Humboldt.

Rangel-Churio, J.O. (2000c): La región paramuna y franja aledaña en Colombia. 
- In: Rangel-Churio, J.O. [Ed.]: Colombia Diversidad Biótica III: La región de vida paramuna. 1-23. Bogotá: Instituto de Ciencias Naturales, Instituto Alexander von Humboldt.

Rangel-Churio, J.O. (2006): The biodiversity of the Colombian páramo and its relation to anthropogenic impact. - In: Spehn, E.M., Liberman, M., Körner, C. [Eds.]: Land use change and mountain biodiversity. 103-118. Boca Raton: CRC Press.

Rangel-Churio, J.O., Jaramillo-Mejía, R. (1984): Lista comentada del material herborizado en el transecto Buritaca-La Cumbre. - In: van der Hammen, T., Ruiz-Carranza, P.M. [Eds.]: La Sierra Nevada de Santa Marta (Colombia), transecto Buritaca-La Cumbre. - Studies on Tropical Andean Ecosystems 2: 155176. Berlin: J. Cramer

Rangel-Churio, J.O., Franco-Roselli, M.P. (1985): Observaciones fitoecológicas en varias regiones de vida de la cordillera Central de Colombia. - Caldasia 14(67): 211-249.

Rangel-Churio, J.O., Lozano-Contreras, G. (1986): Un perfil de vegetación entre la Plata (Huila) y el volcán del Puracé. Caldasia 14(68-70): 503-547.

Rangel-Churio, J.O., Velázquez, A. (1997): Métodos de estudio de la vegetación. In: Rangel-Churio, J.O., Lowy-Cerón, P.D., Aguilar-Puentes, M. [Eds.]: Colombia diversidad biótica II: Tipos de vegetación en Colombia. 59-87. Bogotá: Instituto de Ciencias Naturales, IDEAM.

Rangel-Churio, J.O., Ariza-Niño, C.L. (2000): Nuevos tratamientos sobre la vegetación del páramo. La vegetación paramuna de los volcanes de Nariño. In: Rangel-Churio, J.O. [Ed.]: Colombia diversidad biótica III: La región de vida paramuna. 754-784. Bogotá: Instituto de Ciencias Naturales, Instituto Alexander von Humboldt.

Rangel-Churio, J.O., Betancur, J., Celis, M., Fernández-Alonso, J.L., Sarmiento, J., Pinto-Escobar, P. (2000): Flora: Esperamatófitos. - In: Rangel-Churio, J.O. [Ed.]: Colombia diversidad biótica III: La región de vida paramuna. 126378. Bogotá: Instituto de Ciencias Naturales, Instituto Alexander von Humboldt.

Rangel-Churio, J.O., Rivera-Díaz, O., Franco-Roselli, M.P., Torres, J.H., van der Hammen, T., Cleef, A.M. (2005): Catálogo de la flora vascular del Macizo de Tatamá. - In: van der Hammen, T., Rangel-Churio, J.O., Cleef, A.M. [Eds.]: La cordillera Occidental colombiana, transecto Tatamá. - Studies on Tropical Andean Ecosystems 6: 287-376. Berlin: J. Cramer.

Rangel-Churio, J.O., Sánchez, D. (2005): La flora del páramo de Frontino. - In: van der Hammen, T., Rangel-Churio, J.O., Cleef, A.M. [Eds.]: La cordillera Occidental colombiana, transecto
Tatamá. - Studies on Tropical Andean Ecosystems 6: 833-858. Berlin: J Cramer.

Rangel-Churio, J.O., Arellano-Peña, H. (2007a): Los ecosistemas de la alta montaña de Perijá. - In: Rangel-Churio, J.O. [Ed.]: Colombia diversidad biótica V: La alta montaña de la Serranía de Perijá. 329-346. Bogotá: Instituto de Ciencias Naturales, CORPOCESAR

Rangel-Churio, J.O., Arellano-Peña, H. (2007b): Vegetación de la alta montaña de Perijá. - In: Rangel-Churio, J.O. [Ed.]: Colombia diversidad biótica V: La alta montaña de la Serranía de Perijá 173-192. Bogotá: Instituto de Ciencias Naturales, CORPOCESAR.

Rangel-Churio, J.O., Arellano-Peña, H. (2010): Bosques de Polylepis: Un tipo de vegetación condenado a la extinción. - In: Rangel-Churio, J.O. [Ed.]: Colombia diversidad biótica $\mathbf{X}$ : Cambio global (natural) y climático (antrópico) en el páramo colombiano. 443-478. Bogotá: Instituto de Ciencias Naturales, Universidad Nacional de Colombia.

RBG Kew, MBG [Royal Botanic Gardens Kew \& Missouri Botanical Garden] (2011): The Plant List. - URL http://www.theplantlist.org/ [accessed 2011].

Rivera-Díaz, O. (2007): Caracterización florística de la alta montaña de Perijá. In: Rangel-Churio, J.O. [Ed.]: Colombia diversidad biótica V: La alta montaña de la Serranía de Perijá. 71-132. Bogotá: Instituto de Ciencias Naturales, CORPOCESAR

Rivera-Díaz, O., Fernández-Alonso, J.L. (2003): Análisis corológico de la flora endémica de la Serranía de Perijá, Colombia. - Anales del Jardín Botánico de Madrid 60(2): 347-369.

Rodríguez-Eraso, N., Armenteras-Pascual, D., Morales-Rivas, M., Romero-Ruiz, M. (2004): Memoria técnica del mapa de ecosistemas de los Andes colombianos 2000. - Bogotá: Instituto de Investigación de Recursos Biológicos Alexander von Humboldt. URL: http://hermes.humboldt.org.co//ecosiste mas/andes/

Salamanca-Villegas, S. (1991): The vegetation of the páramo and its dynamics in the volcanic massif Ruiz-Tolima (cordillera Central, Colombia). - PhD thesis, University of Amsterdam [deposited at the library of the University of Amsterdam].

Salamanca-Villegas, S., Cleef, A.M., Rangel-Churio, J.O. (2003): The paramo vegetation of the volcanic Ruiz-Tolima massif. - In: van der Hammen, T., dos Santos, A.G. [Eds.]: La cordillera Central colombiana, transecto Parque Los Nevados (última parte). - Studies on Tropical Andean Ecosystems 5: 1-78. Berlin: J. Cramer.

Sánchez-Montaño, R., Rangel-Churio, J.O. (1990): Estudios ecológicos en la cordillera Oriental colombiana V. Análisis fitosociológico de la vegetación de los depósitos turbosos paramunos de los alrededores de Bogotá. - Caldasia 16(77): 155-192.

SI [Smithsonian Institution] (2003): Names in the Cladoniaceae: List of accepted names and synonyms in the lichen family Cladoniaceae. - URL: http://botany.si. edu/lichens/cladoniaceae/index.cfm [accessed on 2008-2010].

Sipman, H.J.M. (1984): Lichens of the Buritaca-La Cumbre transect. - In: van der Hammen, T., Ruiz-Carranza, P.M. [Eds.]: La Sierra Nevada de Santa Marta (Colombia), transecto Buritaca-La Cumbre. - Studies on Tropical Andean Ecosystems 2: 185-188. Berlin: J. Cramer.

Sipman, H.J.M., Aguirre-Ceballos, J., Rangel-Churio, J.O. (2000): Flora: Líquenes. - In: Rangel-Churio, J.O. [Ed.]: Colombia diversidad biótica III: La región de vida paramuna. 379-434. Bogotá: Instituto de Ciencias Naturales, Instituto Alexander von Humboldt.

Sklenáŕ, P., Luteyn, J.L., Ulloa-Ulloa, C., Jørgensen, P.M., Dillon, M.O. (2005): Flora genérica de los páramos: Guía ilustrada de las plantas vasculares. Memoirs of The New York Botanical Garden 92. Bronx: The New York Botanical Garden Press.

Smith, A.R., Pryer, K.M., Schuettpelz, E., Korall, P., Schneider, H., Wolf, P.G. (2006): A classification for extant ferns. - Taxon 55: 705-731. CrossRef

Stančík, D., Peterson, P.M. (2007): A revision of Festuca (Poaceae: Loliinae) in South American paramos. - Contributions from the United States National Herbarium 56. Washington: Smithsonian Institution Scholarly Press.

Sturm, H., Rangel-Churio, J.O. (1985): Ecología de los páramos Andinos: Una visión preliminar integrada. - Biblioteca José Jerónimo Triana 9. Bogotá: Instituto de Ciencias Naturales, Universidad Nacional de Colombia.

Tichý, L. (2002): JUICE, software for vegetation classification. - Journal of Vegetation Science 13: 451-453.

Uribe-Meléndez, J., Gradstein, S.R. (1998): Catalogue of the hepaticae and anthocerotae of Colombia. Bryophytorum Bibliotheca 53. Berlin: J. Cramer.

Uribe-Meléndez, J., Rangel-Churio, J.O. (2000): Flora: Hepáticas. - In: RangelChurio, J.O. [Ed.]: Colombia diversidad biótica III: La región de vida paramuna. 435-472. Bogotá: Instituto de Ciencias Naturales, Instituto Alexander von Humboldt.

USDA [United States Department of Agriculture] (2001): The PLANTS Database. Version 3.1. - URL: http://plants. usda.gov/index.html [accessed 20082010]. 
USDA [United States Department of Agriculture] (2010): GRIN Taxonomy for Plants. - URL: http://www.ars-grin.gov/ cgi-bin/npgs/html/taxgenform.pl? language $=$ en [accessed 2008-2010].

van der Hammen, T. (1973): The Quaternary of Colombia: Introduction to a research project and a series of publications. - Palaeogeography, Palaeoclimatology, Palaeoecology 14: 1-7. CrossRef

van der Hammen, T., González, E. (1960): Upper Pleistocene and Holocene climate and vegetation of the Sabana de Bogotá (Colombia, South America). - Leidse Geologische Mededelingen 25: 261315.

van der Hammen, T., Rangel-Churio, J.O. (1997): El estudio de la vegetación en Colombia (recuento histórico-tareas futuras). - In: Rangel-Churio, J.O.,
Lowy-Cerón, P.D., Aguilar-Puentes, M. [Eds.]: Colombia diversidad biótica II: Tipos de vegetación en Colombia. 1757. Bogotá: Instituto de Ciencias Naturales, IDEAM.

van Reenen, G.B.A., Griffin-III, D., Gradstein, S.R. (1984): Briofitos del transecto Buritaca-La Cumbre. Sierra Nevada de Santa Marta, Colombia. - In: van der Hammen, T., Ruiz-Carranza, P.M. [Eds.]: La Sierra Nevada de Santa Marta (Colombia), transecto Buritaca-La Cumbre. - Studies on Tropical Andean Ecosystems 2: 177-183. Berlin: J. Cramer.

Vargas, W.G., Gómez-Hoyos, N. (2005): Páramo del Duende (Cordillera Occidental): Datos sobre flora y fauna. In: van der Hammen, T., Rangel-Churio, J.O., Cleef, A.M. [Eds.]: La cordillera Occidental colombiana, transecto
Tatamá. - Studies on Tropical Andean Ecosystems 6: 883-894. Berlin: J. Cramer.

Weber, H.E., Moravec, J., Theurillat, J.-P. (2000): International Code of Phytosociological Nomenclature. 3rd edition. Journal of Vegetation Science 11: 739-768.

Jesús Orlando Rangel-Churio* (jorangelc@unal.edu.co) \& Jairo Humberto Pinto-Zárate (jhpintoz@unal.edu.co) Instituto de Ciencias Naturales, Universidad Nacional de Colombia AV KR 30 \# 45-03, Edif. 425 Bogotá, D.C. 111321, COLOMBIA

*Corresponding author 